\title{
Prohexadione-calcium on downy mildew and botrytis bunch rot epidemiology, and yield and technological and phenolic parameters of the Merlot vine cultivar in the highland region of southern Brazil
}

\author{
Juliana Reinehr ${ }^{1}$ (D) Amauri Bogo ${ }^{1^{*}}$ (D) Leo Rufato ${ }^{1}$ (i) Ricardo Trezzi Casa ${ }^{1}$ (D) \\ Fabio Nascimento Silva ${ }^{1}$ (i) Aike Aneliesse Kretzchmar ${ }^{1}$ (D) Giovani Furini ${ }^{1}$ (i) \\ Francine Regianini Nerbass ${ }^{1}$ (10)
}

${ }^{1}$ Programa de Pós-graduação em Produção Vegetal, Centro de Ciências Agroveterinárias (CAV), Universidade do Estado de Santa Catarina (UDESC), 88520-000, Lages, SC, Brasil. E-mail: amauri.bogo@udesc.br. *Corresponding author.

ABSTRACT: Prohexadione-calcium (ProCa) is a gibberellin biosynthesis inhibitor and the objective of this study was to evaluate the effect of ProCa on the downy mildew (DM) and Botrytis bunch rot (BBR) epidemiology, and the yield and technological and phenolic parameters of grape Merlot cultivar. Experiments were carried out in a commercial vineyard in São Joaquim Municipality/SC, Southern Brazil, during the 2017-2018 and 2018-2019 growing seasons. ProCa was applied at four doses and three phenological stages: A) $0 \mathrm{~g}$ ha ${ }^{-1}$ (control); B) $1000 \mathrm{~g} \mathrm{ha}^{-1}$ (inflorescence fully developed); C) $500+500 \mathrm{~g} \mathrm{ha}^{-1}$ (inflorescence fully developeted and full flowering); D) $500+500+500 \mathrm{~g}$ $\mathrm{ha}^{-1}$ (inflorescence fully developed, full flowering, and berries pea-sized). DM and BBR incidence and severity were quantified weekly from the first symptom appearance until harvest, and their epidemiology was compared according to: a) the beginning of symptom appearance; b) the time to reach the maximum disease incidence and severity; c) the maximum value of disease incidence and severity; d) the area under the disease progress curve. In general, there were significant differences in the ProCa doses for all epidemiologic parameters of DM and BBR compared with the control plot; however, there was no significant difference among the ProCa doses. The principal epidemiological variables that differentiated the effect of ProCa on the DM and BBR control were the Smax and AUSDPC. Some yield and technological and phenolic parameters were negatively affected by different doses of ProCa, but it was still a good option for DM and BBR control in highland region of southern Brazil during the 2017-2018 and 2018-2019 growing seasons.

Key words: Vitis vinifera, Plasmopara viticola, Botrytis cinerea, Area under disease progress curve, Grape quality.

Efeitos da prohexadiona de cálcio na epidemiologia do mildio e podridão de botrytis e no desempenho vitícola da cultivar de videira Merlot em região de altitude do sul do Brasil

RESUMO: A prohexadiona-cálcio (ProCa) é um inibidor da biossintese de giberelina e o objetivo desse estudo foi avaliar o efeito do ProCa na epidemiologia do mildio da videira $(M V)$ e da podridão de Botrytis (PB) e no desempenho vitícola da cultivar de videira Merlot. Experimentos foram realizados em um vinhedo comercial no municipio de São Joaquim/SC, Sul do Brasil, durante as safras 2017-2018 e 2018-2019. A ProCa foi aplicada em quatro doses e três estágios fenológicos: A) $0 \mathrm{~g}$ ha $^{-1}$ (controle); B) $1000 \mathrm{~g}$ ha ${ }^{-1}$ (inflorescência totalmente

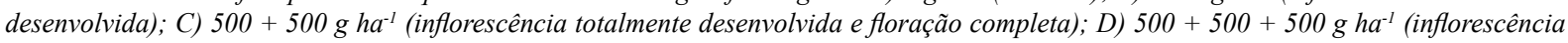
totalmente desenvolvida, floração completa e baga tipo ervilha). A incidencia e severidade de $M V$ e PB foram quantificadas semanalmente a partir do aparecimento dos primeiros sintomas até a colheita e a epidemiologia das doenças foram comparadas de acordo com: a) o início do aparecimento dos sintomas; b) tempo para atingir a máxima incidência e severidade da doença; c) valor máximo da incidência e severidade da doença; d) área abaixo da curva de progresso da doença. Em geral, houve diferenças significativas na dose de ProCa para todos os parâmetros epidemiológicos de $M V$ e PB em comparação com o controle; no entanto, não houve diferença significativa entre as doses de ProCa. As principais variáveis epidemiológicas que diferenciaram o efeito da ProCa no controle do MV e PB foram o $S_{\text {max }}$ e o AUSDPC. Algumas variáveis vitícolas da cultivar Merlot foram afetados negativamente por diferentes doses de ProCa, mas ainda foi uma boa opção o uso da ProCa para o controle do MV e PB em região de altitude do sul do Brasil durante as safras 2017-2018 e 2018-2019.

Palavras-chave: Vitis vinifera, Plasmopara viticola, Botrytis cinerea, Área abaixo da curva de progresso da doença, Qualidade de uva.

\section{INTRODUCTION}

The balance between the vegetative and productive parts of the grape plant is crucial for the success of grape cropping and production with oenological quality (BRIGHENTI et al., 2011). Vegetative growth is mainly influenced by the interaction between canopy and rootstock and characterized by the vigor balance (FELDBERG et al., 2007). Plant imbalance can induce serious problems, 
such as low bud fertility, low canopy aeration and light interception, development and fertilization damage of inflorescences, and reduced control efficiency of some grape diseases (KELLER et al., 2003; ZALAMENA et al., 2013). Additionally, the vegetative/productive imbalance negatively affects the composition, ripening, and phenolic compound content of the grape (DA SILVA et al., 2010).

Several chemicals have been developed to regulate growth plant to reduce the vegetative/ productive imbalance, including Prohexadione-Calcium (ProCa) (PETRACEK et al., 2003). ProCa is a plant growth regulator that acts as a structural mimic of 2-oxoglutaric acid and inhibits late steps of gibberellin biosynthesis, resulting in reduced shoot growth (McGRATH et al., 2009). A current problem has been observed in the São Joaquim region, Santa Catarina State, Southern Brazil, is the association of the vigorous rootstocks Paulsen 1103 with a soil condition with organic matter of more than $8.1 \%$, causing a negative effect of excess vigor of plants and low productivity due to the high concentration of gibberellin at plant growth points.

Additionally, many reports have indicated that ProCa can reduce the intensity of many diseases, such as fire blight in pears, scab in apples, and gray molds in grapes (BAZZI et al., 2003; McGRATH et al., 2009; WALLIS \& COX, 2020). McGrath et al. (2009), suggested that ProCa triggers the production of flavanoids, not normally reported in rosaceous species, that provide antimicrobial activity against $E$. amylovora, and this activity is the primary mechanism of fire blight control by ProCa.

The phenological and technological components of wine have economic importance, and the interaction and variation between them can be evaluated from management techniques applied to the vineyard, fruit ripening, and cultivar features (KENNEDY et al., 2000). Some relevant studies of ProCa on grapevines were performed by SCHILDBERGER et al. (2011). These authors studied the impact of the application of ProCa in the vigorous Vitis vinifera grapevines, especially in cv. Cabernet Franc, Cabernet-Sauvignon, Chardonnay, and Seyval. Based on these studies, the utilization of growth regulators, such as ProCa, showed to be an alternative to manage grapegrowing by reducing and increasing gibberellin $A_{1} \quad\left(G_{1}\right)$ and $A_{20}\left(G_{20}\right)$ levels, respectively. ProCa has been assessed in many crops, such as grapes (LO GIUDICE et al., 2004), and stone fruits (RADEMACHER, 2018) and influenced the management conditions and production.
However, there was no report of the effect of ProCa on Merlot grapes in South Brazil. Therefore, this study evaluated the effect of ProCa on the epidemiology of downy mildew (DM) and Botrytis bunch rot (BBR), and the yield and technological and phenolic parameters in grape Merlot cultivar in Southern Brazil during the 2017-2018 and 20182019 growing seasons.

\section{MATERIALS AND METHODS}

\section{Field trials}

Experiments were carried out in a commercial vineyard ( $V$. vinifera L.) located in the municipality of São Joaquim $\left(28^{\circ} 17^{\prime} 39^{\prime \prime} \mathrm{S}\right.$ and $\left.49^{\circ} 55^{\prime} 56^{\prime \prime} \mathrm{W}\right)$, State of Santa Catarina, Southern Brazil, and conducted during the 2017-2018 and 2018-2019 growing seasons. The vineyard was located at an altitude of $1,430 \mathrm{~m}$ above sea level. The regional climate is humid mesothermic (Cfb) according to the Köppen classification (PEEL et al., 2007), and the soil type is cambisol, with high clay $\left(417 \mathrm{~g} \mathrm{~kg}^{-1}\right)$ and organic matter $\left(81 \mathrm{~g} \mathrm{~kg}^{-1}\right)$ content. In this region, high precipitation occurs from October to March during which, rainfall averages approximately $130 \mathrm{~mm}$ per month. Daily rainfall, relative humidity, and hourly temperatures were recorded at the Santa Catarina Hydrology and Environmental Resources Center-Epagri (Figure 1). The climate data were recorded from September to February, which corresponded to the interval of phenological stages from sprouting - $\mathrm{BBCH} 01$ (September) to harvest - BBCH 89 (February).

The vineyard was composed of approximately 2,200 vines (22 rows of approximately 100 vines) of 15-year-old "Merlot" cultivars grafted onto "Paulsen 1103" rootstock. The vineyard was conducted in vertical shoot positioning, trained at distances of $3.0 \mathrm{~m} \times 1.5 \mathrm{~m}$, arranged along a single east/west-oriented row, and pruned to a double spur cordon at a height of $1.0 \mathrm{~m}$. Irrigation was usually unnecessary because of the adequate rainfall since the annual rainfall in this region was between 1,520$1,620 \mathrm{~mm}$ and regularly distributed throughout the year. The Merlot cultivar is susceptible to DM and $\mathrm{BBR}$, and disease outbreaks have occurred every year in the study region without exception because climatic conditions that promoted these pathogens were present most of the time. Therefore, there was no need to inoculate crops with the pathogens before the proposed study was performed.

Vineyard practices as pruning, leaf removal, and disease control were done according to the recommendations for commercial growers 


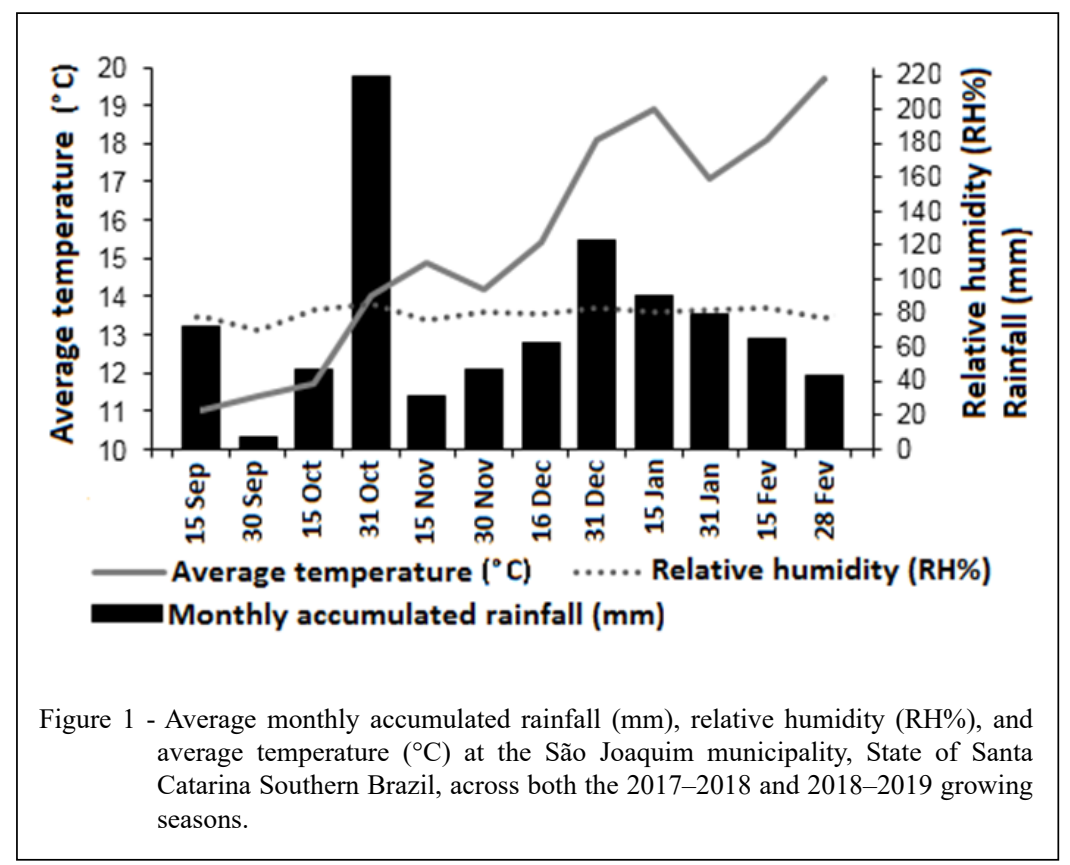

in this region. However, shoot topping was not conducted to protect the vineyard against powdery mildew (Erysiphe necator Schw.) and anthracnose (Elsinoe ampelina Shear). Fenarimol $(500 \mathrm{~mL}$ of active ingredient (a.i) $\left.\mathrm{L}^{-1}\right)$ and folpet $\left(67 \mathrm{~g}\right.$ of a.i $\left.\mathrm{L}^{-1}\right)$, applications, respectively, were performed during the 2017 and 2018 growing seasons. However, low rates of captan $\left(125 \mathrm{~g}\right.$ of a.i $\left.\mathrm{L}^{-1}\right)$ and Metalaxyl + mancozeb $\left(24+192 \mathrm{~g}+\mathrm{mL}\right.$ of a.i $\left.\mathrm{L}^{-1}\right)$ were applied in rotation by spray from September (beginning of bud burst - BBCH 07) to February (harvest - BBCH 89) to maintain low levels of DM and BBR, yet still allow sufficient disease to evaluate the effect of ProCa.

ProCa was applied as Viviful ${ }^{\circledR}\left(275 \mathrm{~g} \mathrm{~L}^{-1}\right.$ of ProCa) ajusted to a volume of $1.000 \mathrm{~L} \mathrm{ha}^{-1}$ at four doses $\left(\mathrm{g} \mathrm{ha}^{-1}\right)$ in the three different phenological, according to BBCH scale (LORENZ at al., 1995): A) $0 \mathrm{~g} \mathrm{ha}^{-1}$ (control); B) 1,000 $\mathrm{g} \mathrm{ha}^{-1}$ (inflorescence fully developed $-\mathrm{BBCH} 57$ ); C) $500+500 \mathrm{~g} \mathrm{ha}^{-1}$ (inflorescence fully developed $-\mathrm{BBCH} 57$ and full flowering - BBCH 65); D) $500+500+500 \mathrm{~g} \mathrm{ha}^{-1}$ (inflorescence fully developed $-\mathrm{BBCH} 57$, full flowering - $\mathrm{BBCH} 65$, and berries pea-sized - $\mathrm{BBCH}$ 75). ProCa was applied to both sides of the canopy, wetting the entirevine, and sprayed withaDreamStime ${ }^{\mathbb{B}}$ atomizer (Canada). The spray gun used a cone nozzle $1,5 \mathrm{~mm}$ in diameter allowing a liquid flow rate of $0,85 \pm 0,02 \mathrm{~L} \mathrm{mim}^{-1}$. ProCa was sprayed early in the morning, without adjuvant, when there was no rain predicted for at least 24 hours. The first, second and thirt ProCa spray was carried out on the $5^{\text {th }}$ of October (inflorescences fully developed - BBCH 57), $24^{\text {th }}$ of October (full flowering $-\mathrm{BBCH} 65$ ), and $07^{\text {th }}$ of December (berries pea-sized - BBCH 75) at 2017 and 2018, respectively, at the 2017/2018 growing season, and at $10^{\text {th }}$ of October (inflorescences fully developed $-\mathrm{BBCH} 57$ ), at $26^{\text {th }}$ of October (full flowering $-\mathrm{BBCH} 65$ ), and $08^{\text {th }}$ of December (berries pea-sized-BBCH 75), respectively, at the 2018/2019 growing season.

\section{$D M$ and $B B R$ intensity}

The incidence and severity of DM and BBR were assessed weekly from the beginning of symptom appearance (BSA) at the end of flowering/ beginning of ripening (November) and end of ripening (February), respectively until harvest (April) during the 2017-2018 and 2018-2019 growing seasons. The incidence and severity of DM were assessed using approximately 25 young leaves per shoot, depending on the available leaves, on four medium-height shoots of each vine in the middle of the plot. These leaves originated from the medial parts of the vine shoots. Shoots with diseased leaves were marked with a plastic tag proximal to the shoot tip to ensure that the same shoot and leaves were surveyed throughout the season. The DM incidence was defined as the number of leaves with DM symptoms divided by the 
total number of leaves evaluated. DM severity was assessed using a visual diagrammatic scale described by BUFFARA et al. (2014) based on seven levels of disease severity: $1 \%, 3 \%, 6 \%, 12 \%, 25 \%, 50 \%$, and $75 \%$. BBR incidence was evaluated by counting disease clusters per five replicates per treatment, and severity was determined by rotted berries per cluster, according to Hill et al. (2010), based on 12 levels of disease severity: $1 \%, 5 \%, 10 \%, 15 \%, 20 \%, 30 \%$, $40 \%, 50 \%, 60 \%, 70 \%, 80 \%$, and $90 \%$. For each plot, 30 random clusters were evaluated per treatment.

The DM and BBR disease progress curves were constructed, and their epidemiology was compared using four epidemiological measures: BSA, time to reach maximum disease incidence/ severity (TRMDI and TRMDS), maximum disease incidence/severity $\left(I_{\max }\right.$ and $S_{\max }$ ), and areas under the severity disease progress curves (AUSDPC). The incidence percentage data were transformed to arcsine multiplied by the square root of the percentage to normalize the data (JEAGER, 2008). The AUSDPC) was calculated as $\Sigma\left[\left(\mathrm{Y}_{\mathrm{i}+} \mathrm{Y}_{\mathrm{i}+} 1\right) / 2\right)\left(\mathrm{t}_{\mathrm{i}+}\right.$ $1 \mathrm{t}_{\mathrm{i}}$ ], where $Y$ is the disease intensity (severity), $t$ is time, and $i$ is the cumulative number of evaluations. These areas represented the trapezoidal integration value of severity (CAMPBELL \& MADDEN, 1990).

\section{Yield parameters}

Two vines of each treatment per plot were selected at the harvest, and the branches and bunches were assessed by the following vegetative and productive parameters: a) vigor, by selecting four branches with similar vigor, approximately the same length by measuring with a tape measure, and with at least one bunch from a middle portion of vine per each treatment, reaching a total of 16 branches per treatment. Branches measure started with ProCa application and repeated biweekly until harvest and considering the final branches leght; b) production $(\mathrm{Kg})$ per plant; c) productivity $\left(\mathrm{kg} \mathrm{ha}^{-1}\right)$ by the multiplication of plant production per vine density (2,200 plants $\left.\mathrm{ha}^{-1}\right)$; and d) Ravaz index, which was estimated using the relationship between the production and the pruning weight. The pruning weight was assessed in the winter during the dormant period. In five randomized bunches per plot, reaching a total of 20 bunches, the following parameters were assessed: e) berry diameter $(\mathrm{cm})$ by a transversal diameter measure of 50 berries per plot, using a digital caliper; f) bunch length (cm); g) bunch mass $(\mathrm{g})$; and $\mathrm{h}$ ) bunch compactness index, where $\mathrm{BCI}=$ [(bunch mass)/(bunch lenght $)^{2}$, according to TELLO \& IBANEZ (2014).

\section{Technological and phenolic parameters}

The monitoring of grape ripening began at veraison, when approximately $50 \%$ of the berries had change color. Each sample consisted of a total of 10 clusters and 150 berries randomly collected per plot/ treatment from different portions (basal, median and apical) of bunches and vine on both sides of the rows, according to RIZZON \& MIELE (2002). All berries were manually crushed one by one to obtain grape must and skin separately. The total soluble solid (TSS) content ( ${ }^{\circ}$ Brix) of grape was determined using a digital temperature compensated refractometer (model Pal-1; Atago, Saitama, Japan); titratable acidity (mg of tartaric acid $100 \mathrm{~g}^{-1}$ grape skin) (OIV, 2008) and $\mathrm{pH}$ were measured with a potentiometer (Impac, São Paulo, Brazil). Total polyphenols (TP; $\mathrm{mg}$ gallic acid $100 \mathrm{~g}^{-1}$ grape skin) (SINGLETON \& ROSSI, 1965) and total monomeric anthocyanins (mg malvidin 3-glucoside $100 \mathrm{~g}^{-1}$ grape skin) (GIUSTI \& WROLSTAD, 2001) were determined using extracts from grape skin macerated for 24 hours at $30 \pm 0.5^{\circ} \mathrm{C}$ and then washed with methanol: $\mathrm{HCl}$ (99:1).

A second extraction using the remains of the skin was performed using the same methodology and both extracts were homogenized and filtered through Whatman 01 filter paper. Both must extract were homogenaized and the final must was assessed by: a) the total soluble solid (TSS) content (Brix) by a digital temperature-compensated refractometer (model Pal-1; Atago, Saitama, Japan); b) the titratable acidity (TA; mg of tartaric acid per $100 \mathrm{~g}^{-1}$ grape skin) (OIV, 2008); c) the $\mathrm{pH}$, using a potentiometer (Impac, São Paulo, Brazil); d) the total polyphenol (mg gallic acid $100 \mathrm{~g}^{-1}$ grape skin) concentration, using a spectrophotometric method described by SINGLETON \& ROSSI (1965), using the FolinCiocalteu reagent with an absorbance of $760 \mathrm{~nm}$, and the phenolic content was determined using a gallic acid calibration curve; e) Total monomeric anthocyanins (mg of malvidin 3-glucoside per $100 \mathrm{~g}^{-1}$ grape skin) using a spectrophotometric method described by Ribéreau-GAYON et al. (1998). The color was determined by a spectrophotometric method described by LEVENGOOD \& BOULTON (2004). The extract was diluted 1:10 with distilled water and analyzed in a spectrophotometer at wavelengths of 420,520 , and $620 \mathrm{~nm}$. The color was measured by the intensity parameter using the following formulas: intensity $=420+520+620 \mathrm{~nm}$.

A completely randomized experimental block was used, which consisted of 10 vines along the rows. These conditions were replicated four times for each treatment, and each treatment was separated by 
buffer rows. Three vines at the end of each plot were necessarily excluded, as were vines at the end of each row and all vines in border rows.

Homogeneity of variance was performed for each year and the two-growing season (20172018 and 2018-2019) averages and variances were statistically compared, using $\mathrm{F}$ test and Bartlett test, respectively. The analysis of averages and variances generated a $\mathrm{p}>0.05$, indicating a non-significant difference and both growing season data were analysed through averages of variables.

Significance tests were performed using analysis of variance, and Dunnett's test was performed in collaboration with Duncan's test ( $p=$ 0.05 ). SAS software, version 9.1 (Cary, NC) was used for data analysis.

\section{RESULTS}

Weather conditions were very similar in each season $\left(2017-2018 ; 14.8^{\circ} \mathrm{C}, 80.3 \%\right.$, and $68.6 \mathrm{~mm}$ ) and $\left(2018-2019 ; 15.6^{\circ} \mathrm{C}, 81.0 \%\right.$ and $\left.76.5 \mathrm{~mm}\right)$ from September (sprouting) to February (harvest). The average temperature in September (sprouting) was around $11-12{ }^{\circ} \mathrm{C}$ and reaching around $15-16^{\circ} \mathrm{C}, 18-19$ ${ }^{\circ} \mathrm{C}$ and $19-20{ }^{\circ} \mathrm{C}$ in the course of spring, summer and end of February (harvest), respectively (Figure 1). These temperatures are considered lower than other Southern Brazil grape production areas, specially regarding to spring and summer.

In general, there were significant differences in the ProCa effect for all epidemiological parameters of DM and BBR compared with the control plot; however, there was no significant difference among ProCa doses. All ProCa doses applied at different phenological stages showed lower BSA, TRMDI and TRMDS, $I_{\max }$ and $S_{\max }$, and AUDPC (Table 1), when compared with the control plot, indicating the positive effect of ProCa on the $\mathrm{DM}$ and BBR control.

The first symptoms of DM appeared by the beginning of November 2017 and the middle of November 2018, which corresponded to the phenological stage of full bloom in 2017 and fruit set in 2018. There was a significant difference in the BSA among ProCa doses when compared with the control plot, with the dose of $1000 \mathrm{~g} \mathrm{ha}^{-1}$ applied at inflorescence fully developed - BBCH 57 , showing the lowest BSA for DM and BBR. The BSA started 42 and 33 days later for DM and BBR for the dose of $1000 \mathrm{~g} \mathrm{ha}^{-1}$ applied at inflorescence fully developed - BBCH 57 and the dose of $500+500+500 \mathrm{~g} \mathrm{ha}^{-1}$ applied at inflorescence fully developed $-\mathrm{BBCH}$
57; respectively, as compared with the control plot (Table1). There was no significant difference among doses for TRMDI and TRMDS; however, the dose of $500+500+500 \mathrm{~g} \mathrm{ha}^{-1}$ applied at inflorescence fully developed - BBCH 57 was the only significant different for DM (Table 1). The $I_{\max }$ and $S_{\max }$ did not show any significant difference among doses. The dose of $1000 \mathrm{~g} \mathrm{ha}^{-1}$ applied at inflorescence fully developed - BBCH 57 showing the lowest $\mathrm{S}_{\max }$ and AUDPC, and indicated the positive effect of ProCa on the DM and BBR epidemiology (Table 1).

The severity and AUSDPC of DM and BBR were both low for all ProCa doses and were lowest for the dose of $1000 \mathrm{~g} \mathrm{ha}^{-1}$ applied at inflorescence fully developed - BBCH 57, compared with the control plot, during both the 2017-2018 and 2018-2019 growing seasons (Table 1). Epidemiological variables were estimated for each dose according to year, and the estimates showed that the principal variables that differentiated the effect of ProCa was the $S_{\max }$ and AUSDPC. The BSA, TRMDI, TRMDS, and AUSDPC showed that the DM and BBR development was low in all the ProCa doses, with the lowest value in the $\mathrm{B}$ dose, as compared with that in the control plot (Table 1). Thus, the B dose was the most efficient in preventing or suppressing disease development, according to the AUSDPC in this experiment (Table 1).

There was no significant difference among the ProCa doses on Merlot grape vigor assessed by final branch length in both the 2017-2018 and 2018-2019 growing seasons (Table 2). Most of the yield and technological and phenolic parameters were affected by different doses of ProCa, except for bunch lenght, bunch compactness index, titratable acidity, total soluble solid, and $\mathrm{pH}$, respectively (Tables 2, 3). There was a significant difference in the yield parameters of bunch mass, bunch lenght, bunch diameter, production, productivity, and ravaz index (Table 2), and the technological and phenolic parameters of color intensity, total polyphenols, and anthocyanin content (Table 3). The yield parameters of vigor and bunch compactness index and the technological and phenolic parameters of total soluble solid, titratable acidity, and $\mathrm{pH}$ were not affected by any of the ProCa doses (Table 3). There was no significant difference in the brunch lenght and bunch compactness index in both the 2017-2018 and 2018-2019 growing seasons (Table 2).

The production and productivity were more affected by different ProCa doses than the control plot in both the 2017-2018 and 2018-2019 growing seasons. The dose of $1000 \mathrm{~g} \mathrm{ha}^{-1}$ applied 
Table 1 - The effect of different doses of Prohexadione-Calcium (ProCa) on the characteristics of downy mildew (DM) and Botrytis bunch rot (BBR) diseases: beginning of symptom appearance (BSA), time to reach the maximum disease incidence (TRMDI) and severity (TRMDS), maximum value of disease incidence $\left(\mathrm{I}_{\max }\right)$ and severity $\left(\mathrm{S}_{\max }\right)$, and area under the severity disease progress curve (AUSDPC) of the Merlot grape during the 2017-2018 and 2018-2019 growing seasons at São Joaquim municipality, State of Santa Catarina, Southern Brazil.

\begin{tabular}{|c|c|c|c|c|c|c|}
\hline Variables & Diseases & A & B & $\mathrm{C}$ & $\mathrm{D}$ & $\mathrm{CV}(\%)^{\mathrm{c}}$ \\
\hline \multirow[b]{2}{*}{ BSA (days) } & $\mathrm{DM}$ & $12.5 \mathrm{c}^{*}$ & $42.0 \mathrm{a}$ & $31.5 \mathrm{~b}$ & $28.0 \mathrm{~b}$ & 8.7 \\
\hline & BBR & $18 \mathrm{c}$ & $24 b$ & $30 \mathrm{a}$ & $33 \mathrm{a}$ & 6.5 \\
\hline \multirow[b]{2}{*}{ TRMDI (days) } & $\mathrm{DM}$ & $76.5 \mathrm{~b}$ & $94.5 \mathrm{a}$ & $87.5 \mathrm{a}$ & $86.0 \mathrm{a}$ & 6.7 \\
\hline & BBR & $23 \mathrm{~b}$ & $35 \mathrm{a}$ & $38 \mathrm{a}$ & $36 a$ & 14.2 \\
\hline \multirow[b]{2}{*}{ TRMDS (days) } & $\mathrm{DM}$ & $82.0 \mathrm{~b}$ & $98.0 \mathrm{a}$ & $94.5 \mathrm{a}$ & $98.0 \mathrm{a}$ & 6.7 \\
\hline & BBR & $33 \mathrm{~b}$ & $48 \mathrm{a}$ & $46 \mathrm{a}$ & $46 \mathrm{a}$ & 14.2 \\
\hline \multirow[b]{2}{*}{$I_{\max } \cdot(\%)$} & $\mathrm{DM}$ & $85.2 \mathrm{a}$ & $74.2 \mathrm{~b}$ & $72.5 b$ & $67.1 \mathrm{~b}$ & 9.6 \\
\hline & $\mathrm{BBR}$ & $55.0 \mathrm{a}$ & $45.0 \mathrm{a}$ & $45.0 \mathrm{a}$ & $45.0 \mathrm{a}$ & 23.8 \\
\hline \multirow{3}{*}{$\mathrm{S}_{\max } \cdot(\%)^{\mathrm{a}}$} & $\mathrm{DM}$ & $28.2 \mathrm{a}$ & $8.8 \mathrm{c}$ & $12.2 \mathrm{~b}$ & $11.7 \mathrm{~b}$ & 12.9 \\
\hline & BBR & $4.4 \mathrm{a}$ & $0.7 \mathrm{c}$ & $1.3 \mathrm{~b}$ & $1.1 \mathrm{~b}$ & 27.1 \\
\hline & $\mathrm{DM}$ & $678.2 \mathrm{a}$ & $216.1 \mathrm{c}$ & $312.1 \mathrm{~b}$ & $305.2 \mathrm{~b}$ & 16.3 \\
\hline AUSDPC $^{b}$ & $\mathrm{BBR}$ & $73.2 \mathrm{a}$ & $10.35 \mathrm{c}$ & $17.65 \mathrm{~b}$ & $23.2 \mathrm{~b}$ & 19.1 \\
\hline
\end{tabular}

A) $0 \mathrm{~g} \mathrm{ha}^{-1}$ (control); B) $1000 \mathrm{~g} \mathrm{ha}^{-1}$ (inflorescences fully developed - BBCH 57); C) $500+500 \mathrm{~g}^{-1}$ (inflorescences fully developed $\mathrm{BBCH} 57$ and full flowering $-\mathrm{BBCH} 65$ ); D) $500+500+500 \mathrm{~g} \mathrm{ha}^{-1}$ (inflorescences fully developed $-\mathrm{BBCH} 57$, full flowering $\mathrm{BBCH} 65$, and barries pea-sized - BBCH 75).

apercentage of leaf (DM) and berry (BBR) area infected using a diagrammatic scale by Buffera et al., (2014) and Hill et al., (2010), respectively.

${ }^{\mathrm{b}}$ Area calculated by the trapezoidal integration value according to Campbell and Madden (1990).

"means followed by the same lower-case letter in the same row are not significantly different (t-test, $p<0.05$ ).

${ }^{c}$ coefficient of variance.

at inflorescence fully developed - $\mathrm{BBCH} 57$ was significantly different among doses, with the highest reduction of production and productivity $(1,203 \mathrm{~g}$ plant $^{-1}$ and $2,673 \mathrm{~kg} \mathrm{ha}^{-1}$, respectively) compared with the control plot $\left(1,712 \mathrm{~g} \mathrm{plant}^{-1}\right.$ and $3,804 \mathrm{~kg}$ $\mathrm{ha}^{-1}$, respectively).

\section{DISCUSSION}

A combination of frequent rain and sustained humidity during spring and summer provided environment conditions that enabled Plasmopara viticola (PV) and Botrytis cinerea (BC) infections. KENNELLY et al. (2005) and HED et al. (2009), showed that for $P$. viticola and B. cinerea, the optimal growth temperature is around $20-25^{\circ} \mathrm{C}$ and $15-23{ }^{\circ} \mathrm{C}$, respectively. Despite of relative low temperatures during most spring and summer, the infection process occured for both $P$. viticola and $B$. cinerea. Usually, the incubation period is shortest at the optimal groth temperatures and when the temperatures are lower, the symptoms will take longer to develop but the epidemy will develop as the temperature increase. The latent period (time from infection to spore production) is expected to take several hours for $B$. cinerea (HED et al., 2009) and 5-18 days for P. viticola (KENNELLY et al., 2005). Thus, it is estimated that $P$. viticola infection may have occurred as early as mid- to late-October, whereas $B$. cinerea infection did not likely occur until December. $B$. cinerea infection early in the season may remain dormant (latent infections) while berries are green, but under favorable conditions, may cause BBR as the grapes approach veraison. In this situation, the diseases can spread rapidly inside the canopy and from berry to berry within clusters and among clusters (HOLZ et al., 2003; KELLER et al., 2003). The harvest season occurred in later February and beginning of March at the 2018 and 2019 growing seasson, respectively; which means that the disease evaluations for 2018 were carried out aproximately 30 days earlier than for 2019 .

The sanitary conditions of Merlot vines and grapes treated either by the fungicides 
Table 2 - The effect of different doses of Prohexadione-Calcium (ProCa) on the yield parameters of the Merlot grape during the 20172018 and 2018-2019 growing seasons at São Joaquim municipality, State of Santa Catarina, Southern Brazil.

\begin{tabular}{|c|c|c|c|c|c|}
\hline Variable & A & B & $\mathrm{C}$ & $\mathrm{D}$ & $\mathrm{CV} \%$ \\
\hline Branch length (cm) & $203.4 \mathrm{a}^{*}$ & $205.3 \mathrm{a}$ & $212.2 \mathrm{a}$ & $201.8 \mathrm{a}$ & 6.08 \\
\hline Bunch mass (g) & $117.4 \mathrm{a}$ & $91.2 \mathrm{~b}$ & $101.2 \mathrm{~b}$ & $83.1 \mathrm{~b}$ & 11.00 \\
\hline Bunch length (cm) & $17.0 \mathrm{a}$ & $13.68 \mathrm{~b}$ & $14.25 \mathrm{~b}$ & $13.93 \mathrm{~b}$ & 8.83 \\
\hline Berry diameter $(\mathrm{cm})$ & $13.61 \mathrm{a}$ & $11.58 \mathrm{~b}$ & $10.87 \mathrm{~b}$ & $10.34 \mathrm{~b}$ & 2.84 \\
\hline Bunch compactness index & $3.55 \mathrm{a}$ & $3.35 \mathrm{a}$ & $3.49 \mathrm{a}$ & $3.01 \mathrm{a}$ & 3.12 \\
\hline Production (g plant $\left.{ }^{-1}\right)$ & $1,712 \mathrm{a}$ & $1,203 \mathrm{c}$ & $1,503 \mathrm{~b}$ & $1,466 \mathrm{~b}$ & 13.23 \\
\hline Productivity $\left(\mathrm{kg} \mathrm{ha}^{-1}\right)$ & $3,804 \mathrm{a}$ & $2,673 \mathrm{c}$ & $3,361 \mathrm{~b}$ & $3,036 \mathrm{~b}$ & 13.23 \\
\hline Ravaz index & $3.39 \mathrm{a}$ & $2.06 \mathrm{~b}$ & $2.44 \mathrm{~b}$ & $2.04 \mathrm{~b}$ & 26.58 \\
\hline
\end{tabular}

A) $0 \mathrm{~g} \mathrm{ha}^{-1}$ (control); B) $1000 \mathrm{~g} \mathrm{ha}^{-1}$ (inflorescences fully developed - BBCH 57); C) $500+500 \mathrm{~g}^{-1}$ (inflorescences fully developed $\mathrm{BBCH} 57$ and full flowering $-\mathrm{BBCH} 65$ ); D) $500+500+500 \mathrm{~g} \mathrm{ha}^{-1}$ (inflorescences fully developed $-\mathrm{BBCH} 57$, full flowering $\mathrm{BBCH} 65$, and barries pea-sized - $\mathrm{BBCH} 75)$.

${ }^{*}$ means followed by the same lower-case letter in the same row are not significantly different (t-test, $\left.p<0.05\right)$.

${ }^{\mathrm{a}}$ coefficient of variance.

and improved by the different doses of ProCa at different phenological stages were improved based on the reduction of DM and BBR intensities. The low inoculum source combined with the fungicides treatment, right ProCa dose, and early phenological stage, diminished the intensity of DM, as well as the smaller size of berries and less compact clusters could affect the reduction of BBR infection, caused by $P$. viticola and $B$. cinerea, respectively.

Favorable climatic and biological conditions for disease development and pathogen infection are very important and fundamental for disease control strategies. Results of this study showed that the ProCa dose of $1000 \mathrm{~g} \mathrm{ha}^{-1}$ applied at inflorescences fully developed - BBCH 57 reduced $\mathrm{DM}$ and BBR intensities in Merlot grapes in the edaphoclimatic conditions of the Santa Catarina State highlands, Southern Brazil, during the 2017-2018 and 2018-2019 growing seasons. The ProCa dose of $1000 \mathrm{~g} \mathrm{ha}^{-1}$ applied at inflorescences fully developed - BBCH 57 was the best system when AUSDPC was taken into account as a differentiated epidemiological variable. During both growing seasons, disease incidence and severity were lower for all doses compared with the control plot. The use of the ProCa dose of $1000 \mathrm{~g} \mathrm{ha}^{-1}$ applied at inflorescences fully developed - $\mathrm{BBCH} 57$, may enable a reduction in the number of fungicide applications, compared with that needed in the control plot without the application of ProCa. However, for further reduction of the severity of both DM and BBR produced by such polycyclic pathogens, the development of $P$. viticola and $B$. cinerea must be decreased by chemical control. The ProCa dose of $1000 \mathrm{~g} \mathrm{ha}^{-1}$ applied at inflorescences fully developed - BBCH 57 allowed a reduction of both pathogens' inoculum in all parts of the canopy zone. The application of the B dose of ProCa at the vines of Merlot cultivars also showed grape production with better color intensity, TP levels, and anthocyanin content, despite the significant reduction in most yield parameters when compared with the control plot.

ProCa produced a reduction in several yield and technological and phenolic parameters, resulting in reduced production and productivity, as compared with the control plot; however, there were no significant differences among doses. The ProCa application in only one dose $\left(1000 \mathrm{~g} \mathrm{ha}^{-1}\right.$ applied at inflorescences fully developed - $\mathrm{BBCH}$ 57) and the early phenological stage of separated inflorescences was the most efficient in reducing both $\mathrm{DM}$ and BBR intensities, and this may be associated with the concentration dose and phenological stage of the leaves and lower bunch mass and bunch diameter, respectively. This effect was the result of a reduction in the fruit set, according to $\mathrm{LO}$ GIUDICE et al. (2004). The author described that ProCa can potentially reduce the fruit set, particularly at the pre-blooming stage, and particularly, in this study, where the dose of $1000 \mathrm{~g} \mathrm{ha}^{-1}$ was applied at inflorescences fully developed - $\mathrm{BBCH}$ 57). The ProCa application at the pre-blooming stage caused browning and abscission of flowers by inhibiting the conversion of 1-aminocyclopropanecarboxylic acid into ethylene, and its application reduced 
Table 3 - The effect of different doses of Prohexadione-Calcium (ProCa) on the technological and phenolic parameters of the Merlot grape during the 2017-2018 and 2018-2019 growing seasons at São Joaquim municipality, State of Santa Catarina, Southern Brazil.

\begin{tabular}{lccccc}
\hline Variables & A & B & C & D & CV $(\%)^{\mathrm{a}}$ \\
\hline Titratable acidity $\left(\mathrm{meq} \mathrm{L}^{-1}\right)$ & $132.1 \mathrm{a}^{*}$ & $132.2 \mathrm{a}$ & $132.4 \mathrm{a}$ & $131.3 \mathrm{a}$ & 0.93 \\
Total soluble solid & $18.6 \mathrm{a}$ & $18.9 \mathrm{a}$ & $18.9 \mathrm{a}$ & $18.8 \mathrm{a}$ & 1.07 \\
$\mathrm{pH}$ & $2.8 \mathrm{a}$ & $3.0 \mathrm{a}$ & $2.9 \mathrm{a}$ & $2.9 \mathrm{a}$ & 0.89 \\
Color intensity & $6.8 \mathrm{~b}$ & $8.7 \mathrm{a}$ & $9.2 \mathrm{a}$ & $10.6 \mathrm{a}$ & 4.58 \\
Total polyphenols $\left(\mathrm{mg} \mathrm{L}^{-1}\right)$ & $2,013.8 \mathrm{c}$ & $2,776.3 \mathrm{~b}$ & $3,034.6 \mathrm{a}$ & $3,080.5 \mathrm{a}$ & 9.81 \\
Anthocyanin $\left(\mathrm{mg} \mathrm{L}^{-1}\right)$ & $1,054.0 \mathrm{c}$ & $1,295.0 \mathrm{a}$ & $1,242.7 \mathrm{a}$ & $1,379.6 \mathrm{a}$ & 2.10 \\
\hline
\end{tabular}

A) $0 \mathrm{~g} \mathrm{ha}^{-1}$ (control); B) $1000 \mathrm{~g} \mathrm{ha}^{-1}$ (inflorescences fully developed - BBCH 57); C) $500+500 \mathrm{~g}^{-1}$ (inflorescences fully developed $\mathrm{BBCH} 57$ and full flowering $-\mathrm{BBCH} 65$ ); D) $500+500+500 \mathrm{~g} \mathrm{ha}^{-1}$ (inflorescences fully developed $-\mathrm{BBCH} 57$, full flowering $\mathrm{BBCH} 65$, and barries pea-sized - BBCH 75).

${ }^{*}$ means followed by the same lower-case letter in the same row are not significantly different ( $\mathrm{t}$-test, $p<0.05$ ).

${ }^{\mathrm{a}}$ coefficient of variance.

ethylene-induced senescence in several plant systems (RADEMACHER, 2018). Despite some of the negative effects of ProCa on the yield and technological and phenolic parameters, it can serve as an alternative option in some grape production areas, especially in the highland regions of Southern Brazil, where DM and BBR infestation can be the main problem every year based on its recurring favorable environmental conditions for pathogenic growth.

ProCa application on Merlot grapes did not show any effect on plant vigor reduction based on the final branches lenght that did not show significant difference. Lo Giudice et al. (2004) showed similar effects to Cabernet franc, Cabernet Sauvignon, Chardonnay, and Seyval, having minimal effects on branch lenght or crop yield after ProCa treatment, compared with that of the control plot. Some cultivation characteristics are determinate to explain the ProCa effect on plant vigor, whereas plants with excessive vigor used to be unresponsive to ProCa application. The differences between treated and control plots were observed either in some yield or technological and phenolic parameters in both growing seasons. The reason why ProCa has different effects over these parameters is still not clear, and the vines could have not been sensitive to the product due to the climatological and environmental conditions, as well as the phenological stage.

THOMIDIS et al. (2018) showed that ProCa sprayed on grapes at the phenological stage of pre- and post-blooming can significantly reduce BBR intensity. According to BAZZI et al. (2003), frequent application of ProCa can induce pathogen resistance by biosynthesis of 3-deoxyflavonoids that act with similar features of phytoalexins, which is responsible for the plants' defense mechanism against pathogens and infections. Furthermore, this study showed several significant effects of ProCa on bunch mass, bunch lenght, and bunch diameter, affecting the bunch architecture and preventing the berries to $B$. cinerea infection (MOLITOR et al., 2011; SCHILDBERGER et al., 2011). PUHL et al. (2008) and MCGRATH et al. (2009) and COSTA et al., (2001), showed that aerial spraying of ProCa can reduce E. amylovora infection in apples and pears, respectively; although, ProCa did not exhibit any direct microbial activity. Some associations could be related to the present study of the significant effects of ProCa on DM intensity, suggesting that secondary ProCa metabolites, such as phenyl compounds, can be involved in developing plant resistance, microbial compounds, or mechanical barriers.

All ProCa doses affected the bunch architecture (bunch mass, bunch lenght, and bunch diameter) and the Ravaz Index. Several reports indicated that inhibitory substances from gibberellin biosynthesis can be used for achieving branch growth reduction and some changes in bunch architecture (MILLER, 2002; RADEMACHER, 2018). Active gibberellins, such as $\mathrm{GA}_{1}$ and its immediate biologically active precursor, $\mathrm{GA}_{20}$, play an important role in the elongation of Pomaceous branches. ProCa regulates the final stages of gibberellin biosynthesis (KIM et al., 2007) by stimulating the conversion of $\mathrm{GA}_{20}$ to $\mathrm{GA}_{1}$ in order to reduce biologically active levels of gibberellins (RADEMACHER, 2018). 
One reason why there was no significant difference observed among different ProCa doses on yield parameters, such as bunch lenght, bunch diameter, bunch mass, and bunch diameter, could be that ProCa can increase growth by converting inactive GA into its active precursor after the first spray (HAWERROTH et al., 2012). Other relevant GA actions that explain the reduction of production and productivity was reported by Miller (2002), whose studies showed that apportioned doses of ProCa can control GAs and negatively affect some yield parameters, such as the production and productivity of different grape cultivars.

The reduction of Merlot cultivar productivity may be directly related to diameter and weight of the berries. The reduction in the diameter and weight of berries could due to the reduction of the GA action induced by the application of ProCa, leading to small size of the cells inside the berries, resulting in thickened cell walls, creating a physical barrier capable of stopping DM and BBR infection.

The Ravaz Index reduction was directly related to reduced production; however, it was observed based on the low Ravaz Index values that the vines were in vegeto-productive imbalance because the ideal index must be between 5 and 10. BORGHEZAN et al. (2011) showed that a low $\mathrm{RI}$ value is a regular characteristic present in grape cultivars, such as Cabernet-Sauvignon, Merlot, and Sauvignon Blanc in the highland regions of Southern Brazil. This low Ravez Index can promote a vicious cycle, causing high vegetative growth and low yields, often caused by a low degree of sunlight. The low degree of sunlight is a factor of great importance for floral differentiation and fruit maturation since sunlight provides energy (temperature) to developing bud cells (BOTELHO et al., 2006).

The right balance between productivity and fruit quality is a particularly challenging aspiration in viticulture (MARTINS et al., 2018). Currently, the right parameters used for the harvest decision are the sanity and chemical quality of the grape. In this study, the chemical quality of the Merlot grape was not greatly influenced by ProCa application. Similar results were obtained by RUFATO et al. (2014), showing that ProCa application did not affect the chemical quality of Cabernet-Sauvignon and Alvarinho, respectively.

The technological and phenolic parameters color intensity, total polyphenols, and the anthocyanin level, were affected by the different ProCa doses and corroborated with data obtained by RAMIREZ et al. (2017), who reported an increase of $42 \%$ in TP and $68 \%$ in the anthocyanin content of Shiraz grape in Mexico in experiments carried out with the same conditions as the present study. These results are beneficial to grape and wine quality because the color in red wine is a very important attribute, as well as the hue and intensity, which are probable indicators of the quality or defect of a wine. Technically, color is the first sensory attribute evaluated in wine tasting (WIRTH et al., 2012). These specific technological and phenolic parameters (color intensity, total polyphenols and antocyanin) were increased with ProCa application and could be involved in some barries resistance to BBR. However, LO GIUDICE et al. (2004), showed that the increase of these parameters can be explained by an increase in surface to volume ratio of berries, resulting in an increase of these parameters on a per berry basis.

The results clearly demonstrated that ProCa was efficient for controlling DM and BBR and increase some yield and technological and phenolic parameters of Merlot grape in highland region of Southern Brazil. The data presented showed that the result of the application of ProCa depends on different environmental parameters, among which the exact timing of application, the rainfall and the pathogen's infestation pressure. The fact that ProCa could allow a more efficient use for DM and BBR control would be of good interest for Integrated Crop Management, helping or replaycing fungicides in wide use and preventing resistance formation.

\section{CONCLUSION}

All ProCa doses applied at different phenological stages showed lower BSA, TRMDI, TRMDS, $I_{\max }, S_{\max }$, and AUDPC of DM and BBR when compared with control plot in both the 2017 2018 and 2018-2019 growing seasons.

ProCa application did not reduce the Merlot grape vigor despite the dose and phenological stage; however, increased the technological and phenolic parameters of color intensity, total polyphernols and the anthocyanin content, in both the 2017-2018 and 2018-2019 growing seasons.

\section{ACKNOWLEDGEMENTS}

This research was financed in part by the Fundação de Amparo a Pesquisa e Inovação do Estado de Santa Catarina (FAPESC), Conselho Nacional de Desenvolvimento Científico e Tecnológico (CNPq), and Coordenação de Aperfeiçoamento de Pessoal de Nível Superior (CAPES), Brasil - Finance code 001. 


\section{DECLARATION OF CONFLICT OF INTEREST}

The authors declare no conflict of interest. The founding sponsors had no role in the design of the study; in the collection, analyses, or interpretation of data; in the writing of the manuscript, and in the decision to publish the results.

\section{AUTHORS’ CONTRIBUTIONS}

All authors contributed equally for the conception and writing of the manuscript. All authors critically revised the manuscript and approved of the final version.

\section{REFERENCES}

BAZZI, C. et al. Control of pathogen incidence in pome fruits and other horticultural crop plants with prohexadione-Ca. European Journal of Horticultural Science, v.68, n.3, p.108-114, 2003. Available from: <http:/www.pubhort.org/ejhs/2003/file_5905. pdf $>$. Accessed: Sep. 15, 2018.

BRIGHENTI, A. F. et al. Viticultural performance of cabernet sauvignon grafted on different rootstocks in high altitude regions of Santa Catarina state. Revista Brasileira de Fruticultura, v.33, n.1, p.096-102, 2011. Available from: <http://www.scielo. br//rbf/2011 nahead/aop02211.pdf>. Accessed: Sep. 24, 2018. doi: 10.1590/S0100-29452011005000039.

BOTELHO, R. V. et al. Bud fertility in vines: physiology and factors involved. Ambiência, v.2, n.1, p.129-144, 2006. Available from: <https://revistas.unicentro.br/index.php/ambiencia/article/ view/366/pdf $>$. Accessed: Sep. 24, 2018.

BORGHEZAN, M. et al. Comportamento vegetativo e produtivo da videira e composição da uva em São Joaquim, Santa Catarina. Pesquisa Agropecuária Brasileira, v.46, p.398-405, 2011. Available from: <http://seer.sct.embrapa.br/index.php/pab/article/ view/9915/6294>. Accessed: Sep. 24, 2018. doi: 10.1590/S0100204X2011000400009.

BUFFARA, C. R. S. et al. Elaboration and validation of a diagrammatic scale to assess downy mildew severity in grapevine. Ciencia Rural, vol.44, p.1384-1391, 2014. Available from: <https://www.scielo.br/scielo.php?pid=S010384782014000801384\&script $=$ sci abstract $>$. Accessed: Aug. 16, 2020. doi: 10.1590/0103-8478cr20131548.

CAMPBELL, C. L.; MADDEN, L. V. Introduction to plant disease epidemiology. New York: Wiley, 1990. 560p.

COSTA, G. et al. Prohexadione-Ca (Apogee): Growth regulation and reduced fire blight incidence in pear. HortScience, v.36, p.931933, 2001. Available from: <https://journals.ashs.org/hortsci/ abstract/journals/hortsci/36/5/article-p931.xml>. Accessed: Sep. 15, 2018. doi: 10.21273/HORTSCI.36.5.931.

DA SILVA, L. C. et al. Raleio de cachos em vinhedos de altitude e qualidade do vinho da cultivar Syrah. Pesquisa Agropecuária Brasileira v.44, n.2, p.148-154, 2010. Available from: <http://seer.sct.embrapa. br/index.php/pab/article/view/1076>. Accessed: Sep. 15, 2018.

FELDBERG, N. P. et al. Desempenho agronômico das videiras' Crimson Seedless' e 'Superior Seedless' no norte de Minas Gerais.
Pesquisa Agropecuária Brasileira, v.42, n.6, p.777-783, 2007. Available from: <http://www.scielo.br/pdf/\%0D/pab/v42n6/ v42n6a03.pdf>. Accessed: Sep. 15, 2018.

GIUSTI, M. M.; WROLSTAD, R. E. Characterization and measurement of anthocyanins by UV-Visible spectroscopy. In: WROLSTAD, R. E. (ed.). Current protocols in food analytical chemistry. New York: John Wiley \& Sons, 2001. p.1- 13. Available from: <https://doi.org/10.1002/0471142913. faf0102s00>. Accessed: Aug. 22, 2020.

HAWERROTH, F. J. et al. Reduction of winter pruning and fruit production increase in 'Hosui' pears by prohexadione calcium use. Pesquisa Agropecuária Brasileira, v.47, p.939-947, 2012. Available from: <http://seer.sct.embrapa.br/index.php/pab/article/ view/12115>. Accessed: Sep. 15, 2018. doi: 10.1590/S0100204X2012000700010.

HED, B. et al. Relationship between cluster compactness and bunch rot in Vignoles grapes. Plant Disease, v.93, p.1195-1201, 2009. Available from: <https://apsjournals.apsnet.org/doi/abs/10.1094/ PDIS-93-11-1195> . Accessed: May, 12, 2020. doi: 10.1094/PDIS93-11-1195.

HILL, G. N. et al. Tools for accurate assessment of botrytis bunch rot (Botrytis cinerea) on wine grapes. New Zealand Plant Protection, v.63, p.174-181, 2010. Available from: $<$ https://www.researchgate. net/publication/266022493_Tools_for_accurate_assessment of_botrytis_bunch_rot_Botrytis_cinerea_on_wine_grapes $>$. Accessed: Sep. 15, 2018. doi: 10.30843/nzpp.2010.63.6560.

HOLZ, G. et al. Occurrence of Botrytis cinerea and subsequent disease suppression at different position on leaves and buches of grape. Plant Disease, v.87, p.351-358, 2003. Available from: $\quad<$ https://apsjournals.apsnet.org/doi/abs/10.1094/ PDIS.2003.87.4.351>. Accessed: May, 12, 2020. doi: 10.1094/ PDIS.2003.87.4.351.

KELLER, M. et al. Botrytis cinerea infection in grape flowers: defense reaction, latency and disease expression. Phytopathology, v.93, p.316-322, 2003. Available from: < https://apsjournals.apsnet. org/doi/abs/10.1094/PHYTO.2003.93.3.316>. Accessed: May, 12, 2020. doi: 10.1094/PHYTO.2003.93.3.316.

KENNEDY, J. A. et al. Development of seed polyphenols in berries from Vitis vinifera L. cv. Shiraz. Australian Journal of Grape and Wine Research, v.6, p.244-254, 2000. Available from: <https:// onlinelibrary.wiley.com/doi/abs/10.1111/j.1755-0238.2000. tb00185.x>. Accessed: Sep. 15, 2018. doi: 10.1111/j.17550238.2000.tb00185.x

KENNELLY, M. M. et al. Seasonal development of ontogenic resistance to downy mildew in grape berries and rachises. Phytopathology, v.95, p.445-1452, 2005. Available from: $<$ https:// apsjournals.apsnet.org/doi/abs/10.1094/PHYTO-95-1445>. Accessed: May, 12, 2020. doi: 10.1094/PHYTO-95-1445.

KIM, Y. H. et al. Effects of prohexadione calcium on growth and gibberellins contents of Chrysanthemum morifolium R. cv Monalisa White. Scientia Horticulturae, v.123, p.423-427, 2010. Available from: <https://www.sciencedirect.com/science/article/ abs/pii/S0304423809004567>. Accessed: May, 12, 2020. doi: 10.1016/j.scienta.2009.09.022.

LEVENGOOD, J.; BOULTON, R. The variation in the color due to copigmentation in young cabernet sauvignon wines. In: 
WATERHOUSE, A. L.; KENNEDY, J.A. (Ed.). Red Wine Color. Washington: American Chemical Society, 2004. 314p.

LO GIUDICE, D. et al. Effects of prohexadione-calcium on grape yield components and fruit and wine composition. American Society for Enology and Viticulture, v.55, p.73-83, 2004. Available from: <https://www.ajevonline.org/content/55/1/73. short $>$. Accessed: Sep. 05, 2018.

LORENZ, D. H. et al. Phenological growth stages of the grapevine, Vitis vinifera L. ssp. vinifera. Codes and descriptions according to the extended BBCH scale. Australian Journal of Grape Wine Research, v.1, p.100-103, 1995. Available from: $<$ https://doi.org/10.1111/j.1755-0238.1995.tb00085.x>. Accessed: Aug. 12, 2020

MARTINS, V. et al. Calcium-and hormone-driven regulation of secondary metabolism and cell wall enzymes in grape berry cells. Journal of plant physiology, v.231, p.57-67, 2018. Available from: $<$ https://www.sciencedirect.com/science/ article/pii/S0176161718305571>. Accessed: Oct. 10, 2018. doi: 10.1016/j.jplph.2018.08.011.

McGRATH, M. J. et al. Evidence that prohexadionecalcium induces structural resistance to fire blight infection. Phytopathology, v.99, n.5, p.591-606, 2009. Available from: $<$ https://www.researchgate.net/publication/24262223_Evidence_ that Prohexadione-Calcium Induces Structural Resistance to Fire_Blight_Infection>. Accessed: Oct. 10, 2018. doi: 10.1094/ PHYTO-99-5-0591.

MILLER, S. S. Prohexadione-calcium control vegetative shoot growth in apple. Journal of Tree Fruit Production, v.3, p.1128, 2002. Available from: <https://www.tandfonline.com/doi/ abs/10.1300/J072v03n01 02>. Accessed: Oct. 10, 2018. doi: org/10.1300/J072v03n01_02.

MOLITOR, D. et al. Crop cultural and chemical methods to control grey mould on grapes. Vitis, v.50, n.2, p.81-87, 2011. Available from: <https://www.researchgate.net/publication/232250081_ Crop_cultural and chemical_methods_to_control_grey_mould on_grapes>. Accessed: Oct. 10, 2018.

OIV. Recueil des méthodes internationales d'analyse des vins et des moûts. Office international de la vigne et du vin. Paris, 2008. 368p.

PEEL, M. C. et al. Updated world map of the Koppen-Geiger climate classification. Hydrology Earth Systemic Science, v.11, p.633-1644, 2007. Available from: <https://hal. archives-ouvertes.fr/hal-00298818/document>. Accessed: May, 12, 2020.

PETRACEK, P. D. et al. A history of commercial plant growth regulators in apple production. HortScience, v.38, p.937942, 2003. Available from: <https://www.researchgate.net/ publication/287573087 A History of Commercial Plant Growth_Regulators_in_Apple_Production $>$. Accessed: Oct. 10,

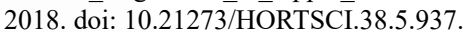

PUHL, I. et al. Alterations of flavonoid biosynthesis in young grapevine (Vitis vinifera L.) leaves. flowers. and berries induced by the dioxygenase inhibitor prohexadione-Ca. Journal of agricultural and food chemistry, v.56, p.2498-2504, 2008. Available from: $<$ https://pubs.acs.org/doi/abs/10.1021/jf0727645>. Accessed: Sep. 28, 2018. doi: 10.1021/jf0727645.
RADEMACHER, W. Chemical regulators of Gibberellin status and their application in plant Production. Annual Plant Reviews, v.49, p.359-403, 2018. Available from: <http:// onlinelibrary.wiley.com>. Accessed: May, 12, 2020. doi: 10.1002/9781119312994.apr0541.

RAMIREZ, $H$. et al. Prohexadione-ca increases yield and antioxidants content in grape cultivar shiraz. Ecosistemas y recur. Agropecuarios, v.4, p.13-20, 2017. Available from: $\quad<$ http://www.scielo.org.mx/scielo.php?pid=S200790282017000100013\&script $=$ sci abstract\&tlng=en $>$. Accessed: May, 12, 2020. doi: 10.19136/era.a4n10.829.

RIBÉREAU-GAYON, P. et al. Traité d'oenologie. 2. Chimie du vin stabilisation et traitements. Paris: Dunod, 1998. 519p.

RIZZON, L. A.; MIELE, A. A acidez na vinificação em tinto das uvas Isabel, Cabernet Sauvignon e Cabernet Franc. Ciência Rural, Santa Maria, v.32, n.3, p.511-515, 2002. Available from: $<$ https://www.scielo.br/pdf/cr/v36n3/a36v36n3.pdf $>$. Accessed: Aug. 22, 2020. doi: 10.1590/S0103-84782002000300023.

RUFATO, L. et al. Effects of prohexadione-calcium on yield components and fruit composition of Cabernet Sauvignon in Southern Brazil. 37th OIV Congress, Argentina. 2014.

SINGLETON, V. L.; ROSSI, J. A. Colorimetry of total phenolics with phosphomolybdic - phosphotunestic acids reagents. American Journal of Enology and Viticulture, n.16, p.144158, 1965. Available from: <https://www.ajevonline.org/ content/16/3/144.short>. Accessed: Sep. 28, 2018.

SCHILDBERGER, B. et al. Effects of prohexadione-calcium on grape cluster structure and susceptibility to bunch rot (Botrytis cinerea) in cv. grüner veltliner. Journal of Plant Pathology, v.93, p.33-37, 2011. Available from: <https://www.jstor.org/ stable/41998927?casa_token=yDcmtiqtKoUAAAAA:a23S6ddd YrrzMbAeK7Xe3sgzhMG gPEzUqaHBh7uV0BYc8OrgdVAVy AIS_DxAUGix3 YFyFXLjrnJzYT_uNnpkX1zTsiV3k3TfWvL5JZT-51vkWkcXVQ\&seq=1\#metadata_info_tab_ contents>. Accessed: Sep. 28, 2018.

TELLO, J.; IBÁÑEZ, J. Evaluation of indexes for the quantitative and objective estimation of grapevine bunch compactness. Rev. Vitis, v.53, p.9-16. 2014. Available from: <https://www. researchgate.net/profile/Javier_Tello/publication/260317676_ Evaluation of indexes for the quantitative and objective estimation_of_grapevine_bunch_compactness/links/54c9f1b 6 0cf2f0b56c25082c.pdf $>$. Accessed: Sep. 28, 2018. doi: 10.5073/ vitis.2014.53.9-16.

THOMIDIS, T. et al. Effect of prohexadione-Ca on leaf chlorophyll content. gas exchange. berry size and composition. wine quality and disease susceptibility in Vitis vinifera L. cv Xinomavro. Scientia Horticulturae, v.238, p.369-374, 2018. Available from: <https://www.sciencedirect.com/science/ article/pii/S0304423818303352>. Accessed: Sep. 28, 2018. doi: org/10.1016/j.scienta.2018.05.008.

ZALAMENA, J. et al. Produtividade e composição de uva e de vinho de videiras consorciadas com plantas de cobertura. Pesquisa Agropecuária Brasileira, v.48, p.182-189, 2013. Available from: <http://seer.sct.embrapa.br/index.php/pab/article/ view/12823>. Accessed: Sep. 15, 2018. doi: 10.1590/S0100204X2013000200008. 
WALLIS, A. E.; COX, K. D. Management of Fire Blight Using Pre-bloom Application of Prohexadione-Calcium. Plant Disease, v.104, p.177-185, 2020. Avalilable from: <https://apsjournals. apsnet.org/doi/full/10.1094/PDIS-09-19-1948-RE>. Accessed: May, 12, 2020. doi: 10.1094/PDIS-09-19-1948-RE.
WIRTH, J. et al. Impact of post-bottling oxygen exposure on the sensory characteristics and phenolic composition of Grenacherosé wines. Food Chemistry, n.132, p.1861-187, 2012. Available from: <https:// www.sciencedirect.com/science/article/pii/S0308814611017742>. Accessed: Sep. 15, 2018. doi: 10.1016/j.foodchem.2011.12.019. 